\title{
The potency of Sansevieria trifasciata and S. cylindrica leaves extracts as an antibacterial against Pseudomonas aeruginosa
}

\author{
WHIKA FEBRIA DEWATISARI ${ }^{1}$, LAURENTIUS HARTANTO NUGROHO ${ }^{2, *}$, ENDAH RETNANINGRUM $^{2}$, \\ YEKTI ASIH PURWESTRI ${ }^{2}$ \\ ${ }^{1}$ Doctoral Program in Tropical Biology, Faculty of Biology, Universitas Gadjah Mada. Jl. Teknika Selatan, Sekip Utara, Sleman 55281, Yogyakarta, \\ Indonesia \\ ${ }^{2}$ Faculty of Biology, Universitas Gadjah Mada. Jl. Teknika Selatan, Sekip Utara, Sleman 55281, Yogyakarta, Indonesia. \\ Tel.: +62-271-580839, Fax.: +62-271-6492355, `email: hartantonugroho2005@ugm.ac.id
}

Manuscript received: 4 December 2020. Revision accepted: 27 December 2020.

\begin{abstract}
Nugroho LH, Dewatisari WF, Retnaningrum E, Purwestri YA. 2021. The potency of Sansevieria trifasciata and S. cylindrica leaves extracts as an antibacterial against Pseudomonas aeruginosa. Biodiversitas 22: 408-415. Sansevieria trifasciata and Sansevieria cylindrica are the major herbs in Indonesia, which contain several bioactive compounds as potential sources of antibacterial agents. This study aims to evaluate the antibacterial activity of $S$. trifasciata and $S$. cylindrica leaves extract and fraction against Pseudomonas aeruginosa and to identify its bioactive compounds. Crude ethanolic extract of S. trifasciata and S. cylindrica leaves were tested for their antimicrobial activity by disk diffusion method against $P$. aeruginosa. S. trifasciata showed strong antibacterial activity with an inhibition zone of $18.3 \mathrm{~mm}$ compared to $S$. cylindrica. Different concentrations of extract i.e. $4 \mathrm{mg} / \mathrm{mL}, 8 \mathrm{mg} / \mathrm{mL}, 16 \mathrm{mg} / \mathrm{mL}, 32$ $\mathrm{mg} / \mathrm{mL}, 64 \mathrm{mg} / \mathrm{mL}, 128 \mathrm{mg} / \mathrm{mL}$ and $256 \mathrm{mg} / \mathrm{mL}$ were tested for their minimum inhibitory concentrations (MIC). The MIC results showed that the $S$. trifasciata extract was able to inhibit bacterial growth at a concentration of $32 \mathrm{mg} / \mathrm{mL}$. Results of vacuum liquid chromatography (VLC) and thin-layer chromatography (TLC) revealed that only fraction 3 showed the highest antibacterial activity at $16 \mathrm{mg} / \mathrm{mL}$. In TLC bioautography analysis, fraction 3 showed a clear zone at $\mathrm{Rf} 0.93$. The phytochemical analysis showed that terpenoid, phenolic, triterpenoid, and flavonoid compounds were found in S. trifasciata extract that were associated with antibacterial activity.
\end{abstract}

Keywords: Antibacterial, ethanolic extract, Pseudomonas aeruginosa, Sansevieria cylindrica, Sansevieria trifasciata

\section{INTRODUCTION}

Sansevieria trifasciata and S. cylindrica are plants that have therapeutic potential and easy to grow in Indonesia. Sansevieria trifasciata has round, leathery and stiff leaves while S. cylindrica has flat, sword-shaped leaves. These plants are distributed in tropical and subtropical areas, with a distribution ranging from Africa to Southeast Asia and the islands of the Indian Ocean (Lu et al. 2014; Umoh et al. 2020). Both plants have ethnobotanical uses that vary in their geographic range. These plants have occupied an important position among plant genera applied to the widespectrum treatment of diseases with immune disorders (Khalumba and Mbugua 2005; Staples and Herbst 2005; Takawira-Nyenya et al. 2014). These species are traditionally used for the treatment of various diseases such as colds, diarrhea, coughs, inflammation of the respiratory tract, swelling, bumps, bruises, ulcers, poisonous snake bites, and hair fertilizers (Berame 2017; Andhare et al. 2012). Sansevieria trifasciata and S. cylindrica have been studied for their pharmacological activities, such as antioxidant, anti-tumor, antidiabetic anaphylaxis, and activity inhibition of capillary permeability (Andhare et al. 2012; Sheela et al. 2012; Tkachenko 2017; Berame et al. 2017; Buyun et al. 2017).

Pseudomonas aeruginosa is a normal bacteria and is pathogenic in low immune conditions due to environmental factors and high stress (Dzen 2003). These bacteria have been known for years as the cause of serious infectious diseases such as eye, ear, chronic respiratory disease, pneumonia, urinary tract, blood vessels, and skin infections (Wu et al. 2015). Compared to other bacteria P. aeruginosa has stronger resistance to the physical environment and chemicals (Umoh 2009; Retnaningrum and Wilopo 2018; Purwestri et al. 2016).

Several studies have reported the antibacterial activity of S. trifasciata and S. cylindrica against $P$. aeruginosa (Kingsley et al. 2013; Buyun et al. 2018). S. trifasciata and $S$. cylindrica leaves contain phytochemicals such as dicarboxylic acids, phenols, steroid saponins, flavonoids, saponins, coumarins, homoisoflavanone, and fatty acid (Said et al. 2015; Berame et al. 2017; Tkachenko 2017; Ahamad et al. 2017; Umoh et al. 2020). Several bioactive compounds have been reported in Sansevieria that are responsible for the antibacterial activity such as quinolone, 3,4-dimethoxybenzoic acid, palmitaldehyde, 1,2-benzenedicarboxylic acid, and delta-undecalactone (Philip 2011; Yumna et al. 2018).

The presence of various chemical compounds attracted researchers to conduct antibacterial testing of ethanolic extract and its fractions. Ethanol is a non-toxic organic solvent used in the extraction of bioactive plant materials. In the present study, extracts were made by multilevel maceration method which is the novelty of this research. 
The objectives of this study were: (i) To compare the antibacterial activity of $S$. trifasciata and $S$. cylindrica leaves extracts and fractions from potential extract against $P$. aeruginosa; (ii) To identify bioactive compounds using TLC reagents.

\section{MATERIALS AND METHODS}

The materials used in the present study were leaves of $S$. trifasciata, $S$. cylindrica, and bacteria $P$. aeruginosa FBGMU 01. The leaves were collected from Bandar Lampung, Lampung, Indonesia (5 $5^{\circ} 21^{\prime} 30.16^{\prime \prime} \mathrm{S} \mid 105^{\circ} 13^{\prime}$ $\left.58.62^{\prime \prime} \mathrm{E}\right)$. The investigation was carried out at the Faculty of Biology Universitas Gadjah Mada (UGM) Yogyakarta, Indonesia. Sansevieria trifasciata and S. cylindrica have been identified in the Plant Systematics Laboratory, Faculty of Biology, Universitas Gadjah Mada with a certificate number 014527/S.Tb.//II/2019. The herbarium $S$. trifasciata and $S$. cylindrica stored in the Plant Systematics Laboratory, Department of Tropical Biology, Faculty of Biology.

\section{Leaves extraction of $S$. trifasciata and $S$. cylindrica}

The leaves of $S$. trifasciata and $S$. cylindrica were first washed with sterile distilled water and dried in oven at $50^{\circ} \mathrm{C}$ for 24 hours. The dried samples were ground using a grinder and then sieved with 40 mesh to obtain fine powder. Then powder sample was extracted by graded maceration method with chloroform solvent, and then the maceration was continued with ethanol. The ratio of plant materials and solvent was 1:3 (w/v)

\section{Determination of antibacterial activity using disk diffusion}

Pseudomonas aeruginosa FBGMU 01 with a cell number of $1.5 \times 10^{8} \mathrm{cfu} / \mathrm{mL}$ which equivalent to turbidity of $0.5 \mathrm{McF}$ arland was inoculated into NA media by pour plate method. Paper discs containing extract with $16 \mathrm{mg} / \mathrm{mL}$, positive control of ciprofloxacin, and negative control of $10 \%$ DMSO were further placed on bacterial culture agar plate. After 24 hours of inoculation, antibacterial activity was analyzed by measuring diameter of inhibition zone.

\section{Minimum Inhibitory Concentration(MIC) determination}

MIC determination was estimated by following the method of Balouiri et al. (2016) and Arung et al. (2017) with slight modification. The different concentrations of $S$. trifasciata leaves extract were used i.e. $4 \mathrm{mg} / \mathrm{mL}, 8$ $\mathrm{mg} / \mathrm{mL}, 16 \mathrm{mg} / \mathrm{mL}, 32 \mathrm{mg} / \mathrm{mL}, 64 \mathrm{mg} / \mathrm{mL}, 128 \mathrm{mg} / \mathrm{mL}$, and $256 \mathrm{mg} / \mathrm{mL}$. $200 \mu \mathrm{L}$ bacterial culture with a cell number of $1.5 \times 10^{8} \mathrm{cfu} / \mathrm{mL}$ were inoculated with $8.8 \mathrm{~mL}$ of $\mathrm{NB}$ medium into a test tube. After incubation at $37^{\circ} \mathrm{C}$ for 24 hours, the growth of $P$. aeruginosa was observed and measured using optical density using the Elisa Reader at wavelength at $595 \mathrm{~nm}$.

\section{Fractionation using Vaccum Liquid Chromatography (VLC)}

For VLC fractionations, twelve grams of silica gel 60 GF254 (Merck) was used as the stationary phase. The leaves extract of $S$. trifasciata (2.5 grams) was mixed with $5 \mathrm{~g}$ of GF254 silica gel powder. The mobile phase used was a mixture of $\mathrm{n}$-hexane: chloroform $3: 1(\mathrm{v} / \mathrm{v}), 2: 2(\mathrm{v} / \mathrm{v}), 1$ : 3 (v/v), $100 \%$ chloroform, chloroform: ethanol 3: $1(\mathrm{v} / \mathrm{v})$, 2: $2(\mathrm{v} / \mathrm{v}), 1: 3(\mathrm{v} / \mathrm{v}), 100 \%$ ethanol. Eluent was then collected in a $10 \mathrm{~mL}$ vial tube followed by Thin Layer Chromatography (TLC) analysis (Pinteus et al. 2013).

\section{Thin Layer Chromatography (TLC)}

TLC of $S$. trifasciata extract was carried out with silica gel F254 (E. Merck) as a stationary phase and ethyl acetate-methanol (3: 2) as mobile phase. Chromatogram detection was measured at 254 and $366 \mathrm{~nm}$ ultraviolet light. The same pattern in the results of the TLC analysis was combined into one fraction.

\section{Bioautography}

Bioautography of the tested bacteria was carried out by placing the TLC plate containing the chromatogram of the potential fraction on the NB medium which already contained the tested bacteria. The TLC plates were left to stand for 30 minutes then incubated at $37^{\circ} \mathrm{C}$ for $18-24$ hours. The presence of a clear zone (no growth of bacterial colonies) after incubation indicates that the chromatogram spots contain antibacterial compounds (Dewanjee et al 2015). The spots showed the clear zone was calculated by retardation factor $(\mathrm{Rf})$ value by: $\mathrm{Rf}=$ Distance traveled by spot/Distance traveled by solvent

\section{Identification of bioactive compounds using TLC Reagents}

The potential fraction was assessed for the existence of the phytochemical analysis by using the standard methods according to Jork (1994). Chromatogram sprayed with various reagents: (i) Vanillin/Sulfuric acid indicated the presence of terpenoid, steroid, phenols, and essential oil, (ii) Iron(III) chloride for phenols; (iii) Lieberman-Burchard for triterpenoids; (iv) Aluminum chloride for flavonoid, and (5) Dragendorff's Reagent for alkaloid.

The chromatogram observed under UV $254 \mathrm{~nm}$ and 366 $\mathrm{nm}$ was then sprayed with the coloring reagent Dragendorff reagent that produced orange color for alkaloid, Aluminum chloride that produced yellow color for flavanoid, and sulfate vanillin that produced purple color for terpenoid. Analysis of secondary metabolites compounds was done by the measurement of $\mathrm{Rf}$ value.

\section{Data analysis}

All the experiments were repeated three times. The results obtained were analyzed qualitatively and quantitatively. The data were processed using SPSS 26 and analyzed using one-way ANOVA at a confidence level of $95 \%$ and the significance value is $\mathrm{P}<0.05$. 


\section{RESULTS AND DISCUSSION}

The antibacterial activity of crude extract of Sansevieria trifasciata and S. cylindrica leaves

The ethanolic extract of $S$. trifasciata leaves showed strong antibacterial activity against $P$. aeruginosa with $18.33 \pm 0.53 \mathrm{~mm}$ zone of inhibition while moderate antibacterial activity $10.33 \pm 0.58 \mathrm{~mm}$ was recorded in $S$. cylindrica (Table 1). Ciprofloxacin exhibited strong inhibition zone with $31.17 \mathrm{~mm}$. For the negative control, DMSO $10 \%$ showed no $(0.00 \mathrm{~mm})$ inhibition zone (Figure 1). The crude extract of $S$. trifasciata leaves had higher antibacterial activity than the $S$. cylindrica and was significantly $(\mathrm{p}<0.05)$ different. Out of two extracts, only $S$. trifasciata extract showed high area of inhibition, so it was used for further tests.

\section{Minimum inhibitory concentration of Sansevieria trifasciata leaves extract}

Results revealed that lowest $4 \mathrm{mg} / \mathrm{mL}$ MIC value recorded from leaves extract of $S$. trifasciata which inhibited bacterial growth. At this concentration, the tube looks clearer than the positive control. In optical density measurement using ELISA Reader, the reduced bacterial population $\geq 50 \%$ was obtained at a concentration of 32 $\mathrm{mg} / \mathrm{mL}$ (Figure 2, Table 2).

\section{Fraction of Sansevieria trifasciata leaves}

The results showed that total of eight fractions of $S$. trifasciata was obtained using VLC. Out of eight, four fractions were then tested for their antibacterial activity by disk diffusion method. The largest inhibition zone of $S$. trifasciata leaves extract fraction was noted in fraction 3 $(13.00 \mathrm{~mm})$ followed by fraction $4(9.69 \mathrm{~mm})$, fraction 2
$(6.00 \mathrm{~mm})$, and fraction $1(5.50 \mathrm{~mm})$ The fraction 3 of $S$. trifasciata leaves showed the best antibacterial activity (Table 3, Figure 3).

Table 1. Antibacterial activity of Sansevieria trifasciata and $S$. cylindrica leaves extract based on disk diffusion methods

\begin{tabular}{lll}
\hline Extract & $\begin{array}{l}\text { Diameter of zone } \\
\text { inhibition }(\mathbf{m m})\end{array}$ & $\begin{array}{l}\text { Antibacterial } \\
\text { activity }\end{array}$ \\
\hline $\mathrm{DMSO}(10 \%)(-)$ & $0 \pm 0.00^{\mathrm{a}}$ & Weak \\
Ciprofloxacin (+) & $31.83 \pm 0.87^{\mathrm{d}}$ & Very strong \\
S. trifasciata & $18.33 \pm 0.53^{\mathrm{c}}$ & Strong \\
S. cylindrica & $10.33 \pm 0.58^{\mathrm{b}}$ & Moderate \\
\hline
\end{tabular}

Note: *The values of antibacterial activity represented by mean \pm standard error from 3 replications; Different superscript alphabetic letters were significantly different at $(p<0.05)$ by Tukey test

Table 2. Minimum inhibitory concentration activity at various concentrations of Sansevieria trifasciata leaves extract

\begin{tabular}{ll}
\hline \multicolumn{1}{c}{ Extract $(\mathbf{m g} / \mathbf{m L})$} & \multicolumn{1}{c}{ Optical Density \pm SD } \\
\hline NB \& bacteria $(+)$ & $0.632 \pm 0.002^{\mathrm{e}}$ \\
4 & $0.573 \pm 0.068^{\mathrm{e}}$ \\
8 & $0.316 \pm 0.011^{\mathrm{d}}$ \\
16 & $0.274 \pm 0.051^{\mathrm{cd}}$ \\
32 & $0.203 \pm 0.014^{\mathrm{bc}}$ \\
64 & $0.194 \pm 0.04^{\mathrm{bc}}$ \\
128 & $0.192 \pm 0.010^{\mathrm{bc}}$ \\
256 & $0.154 \pm 0.026^{\mathrm{b}}$ \\
NB $(-)$ & $0.054 \pm 0.002^{\mathrm{a}}$ \\
\hline
\end{tabular}

Note: $*$ The values of antibacterial activity represented by mean \pm standard error from 3 replications; Different superscript alphabetic letters were significantly different at $(\mathrm{p}<0.05)$ by Tukey test

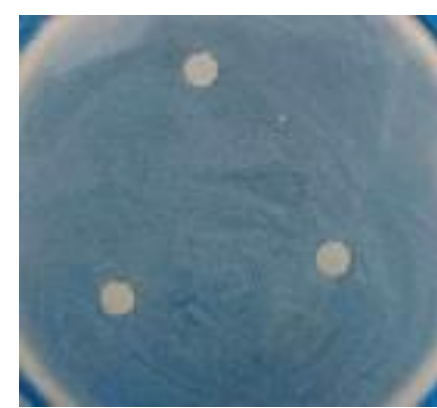

A

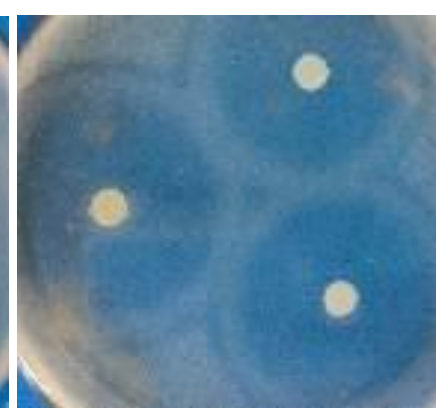

B

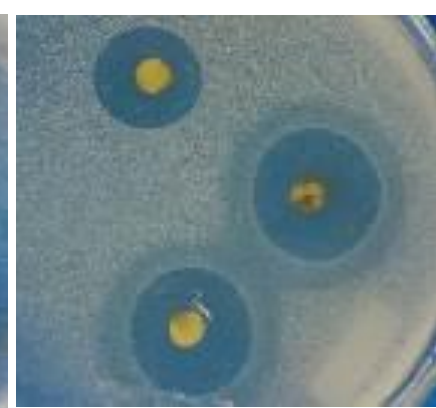

C

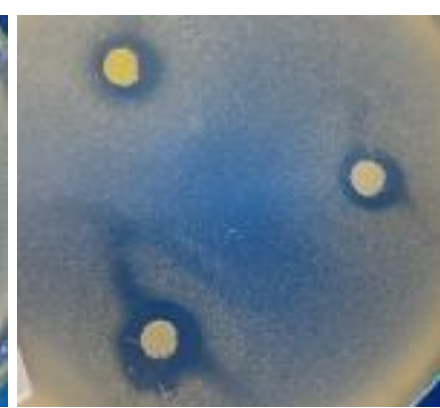

D

Figure 1. The inhibition zones of ethanolic extracts showed antibacterial activity against Pseudomonas aeruginosa. A. DMSO 10\% (-), B. ciprofloxacin (+), C. Sansevieria trifasciata leaves extract, D. S. cylindrica leaves extract

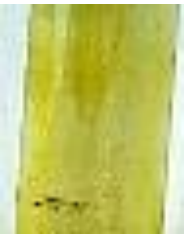

A

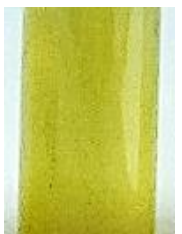

B

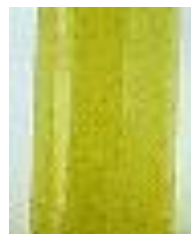

C

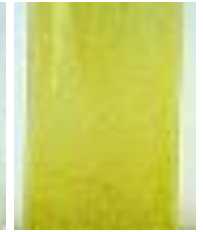

D

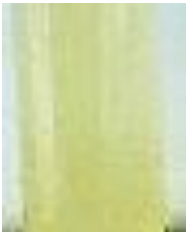

E

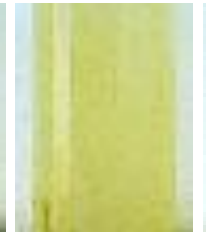

F

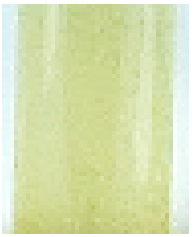

G

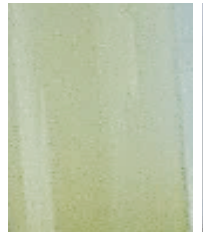

H

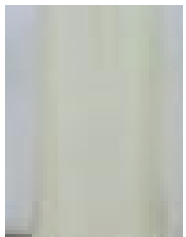

I

Figure 2. The turbidity of Sansevieria trifasciata leaves extract in various concentrations: A. Control positive, B. $4 \mathrm{mg} / \mathrm{mL}, \mathrm{C} .8$ $\mathrm{mg} / \mathrm{mL}$, D. $16 \mathrm{mg} / \mathrm{mL}$, E. $32 \mathrm{mg} / \mathrm{mL}$, F. $64 \mathrm{mg} / \mathrm{mL}$, G. $128 \mathrm{mg} / \mathrm{mL}$, H. $256 \mathrm{mg} / \mathrm{mL}$, I. Control negative 
Based on the Rf value on the TLC spot (Table 4), it can be observed the diversity of the tested isolates. Results exhibited that 3 spots were found in fraction 1,2 spots in fraction 2, 4 spots in fraction 3, and 2 spots in fraction 4 . This showed that the spots that appear in all isolates varied in their number and $\mathrm{Rf}$ value. Therefore, it facilitates the purification of the desired components. The results of bioautographic of $S$. trifasciata leaves extract to test for fraction 3 are presented in Figure 4. The resulting fraction was then performed TLC-bioautography. The results of TLC are presented in Figure 4.

The results of bioautography on TLC showed three clear zones, with only fraction 3 found to be against $P$. aeruginosa. The clear zone appeared at $\mathrm{Rf} 0.93$. Thus, it showed that the spot contains bioactive compounds that can inhibit the growth of $P$. aeruginosa. The greatest inhibition zone appeared at Rf 0.93 . The inhibition zone appeared because bioactive compounds diffuse into the media and inhibit the growth of $P$. aeruginosa. Other fractions also showed a clear zone, but the inhibition zone was small. This shows that the antibacterial strength was different in these fractions, even though the Rf value was found to be the same. Based on the $\mathrm{Rf}$ value and the type of solvent used in this study, it can be concluded that the active compound is polar. The results of bioautography and disk diffusion test exhibited that fraction 3 had the highest inhibition zone (Figure 5). Fraction 3 was then used for MIC determination. As shown in Table 5, the MIC of fraction 3 obtained was $16 \mathrm{mg} / \mathrm{mL}$.

\section{Identification of bioactive compounds}

Spots of secondary metabolites in TLC plate can be seen in Figure 7. Result indicated that terpenoid was detected in $\mathrm{Rf} 0.625$, Rf 0.69 , and $\mathrm{Rf} 0.93$. Phenolic was detected in $\mathrm{Rf} 0.93$. Triterpenoid was found in $\mathrm{Rf} 0.69$ and Rf 0.93, Flavonoid with Rf 0.69 and Rf 0.93 while the alkaloid was not detected in any plate (Figure 6 and Table 6 ). This showed that the leaves of $S$. trifasciata were containing polar and semipolar compounds.

\section{Discussion}

Plants have been known to produce various chemical components that have different biological activities against various microorganisms (Matic et al. 2016). The inhibition zone of $S$. trifasciata extract against $P$. aeruginosa showed stronger antibacterial activity than $S$. cylindrica. These results differ from research conducted by Buyun et al (2018), the antibacterial activity of S. cylindrica showed $17.8 \mathrm{~mm}$ zone of inhibition against $P$. aeruginosa.
Table 3. Antibacterial activity of 4 fractions obtained from Vacuum Liquid Chromatography

\begin{tabular}{cc}
\hline Fractions & Zone inhibition $(\mathbf{m m})$ \\
\hline DMSO(10\%) (-) & $0 \pm 0.00^{\mathrm{a}}$ \\
Ciprofloxacin $(+)$ & $31.17 \pm 1.94^{\mathrm{e}}$ \\
1 & $5.50 \pm 0.87^{\mathrm{b}}$ \\
2 & $6.00 \pm 1.00^{\mathrm{b}}$ \\
3 & $13.00 \pm 1.00^{\mathrm{d}}$ \\
4 & $9.69 \pm 0.58^{\mathrm{c}}$ \\
\hline
\end{tabular}

Note: *The values of antibacterial activity represented by mean \pm standard error from 3 replications; Different superscript alphabetic letters were significantly different at $(\mathrm{p}<0.05)$ by Tukey test.

Table 4. The Rf value of the TLC chromatogram

\begin{tabular}{|c|c|}
\hline Fraction & $\mathbf{R f}$ \\
\hline F1 & $\begin{array}{l}0 \\
0.81 \\
0.93\end{array}$ \\
\hline $\mathrm{F} 2$ & $\begin{array}{l}0 \\
0.93\end{array}$ \\
\hline $\mathrm{F} 3$ & $\begin{array}{l}0 \\
0.44 \\
0.625 \\
0.69 \\
0.93\end{array}$ \\
\hline $\mathrm{F} 4$ & $\begin{array}{l}0 \\
0.93\end{array}$ \\
\hline
\end{tabular}

Table 5. Minimum inhibitory concentration activity at various concentration fractions of Sansevieria trifasciata leaves

\begin{tabular}{cl}
\hline $\begin{array}{c}\text { Concentration of fraction } \\
(\mathbf{m g} / \mathbf{m L})\end{array}$ & \multicolumn{1}{c}{$\begin{array}{c}\text { Optical Density } \\
\mathbf{\pm} \mathbf{S D}\end{array}$} \\
\hline $\mathrm{NB}+$ bacteria $(+)$ & $0.326 \pm 0.0037^{\mathrm{d}}$ \\
4 & $0.281 \pm 0.006^{\mathrm{d}}$ \\
8 & $0.250 \pm 0.041 \mathrm{c}^{\mathrm{d}}$ \\
16 & $0.187 \pm 0.052^{\mathrm{bc}}$ \\
32 & $0.166 \pm 0.07^{\mathrm{ab}}$ \\
64 & $0.130 \pm 0.02^{\mathrm{ab}}$ \\
128 & $0.122 \pm 0.013^{\mathrm{ab}}$ \\
256 & $0.139 \pm 0.035^{\mathrm{ab}}$ \\
NB (-) & $0.097 \pm 0.006^{\mathrm{a}}$ \\
\hline
\end{tabular}

Note: $*$ The values of antibacterial activity represented by mean \pm standard error from 3 replications; Different superscript alphabetic letters were significantly different at $(\mathrm{p}<0.05)$ by Tukey test

Table 6. Results bioactive compounds present in fraction 3 of Sansevieria trifasciata leaves

\begin{tabular}{llll}
\hline Reagents & Bioactive compound & Interpretation & Color observation \\
\hline Vanillin/sulfuric acid & Terpenoid & Purplish blue, brown & Purplish blue, brown $(+)$ \\
Iron(III) chloride & Phenolic & Purplish gray & Purplish gray $(+)$ \\
Lieberman-Burchard & Triterpenoid & Brownish purple, brown & Brownish purple(+) \\
Aluminum chloride & Flavonoid & Yellow & Light yellow $(+)$ \\
Deggendorf & Alkaloid & Orange & Light green $(-)$ \\
\hline
\end{tabular}




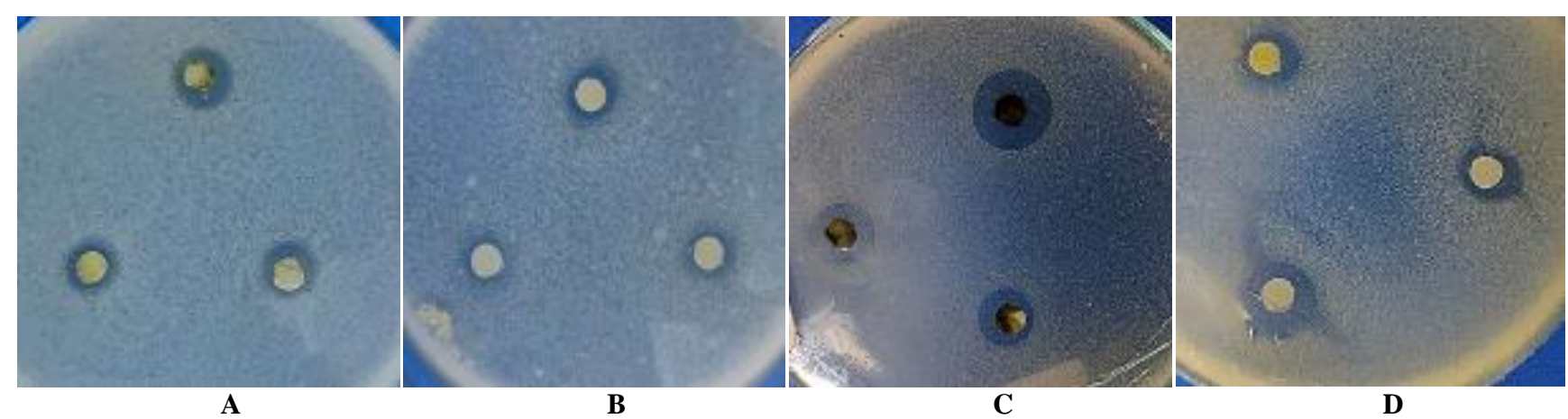

Figure 3. The inhibition zones of Sansevieria trifasciata leaves fraction showed antibacterial activity against Pseudomonas aeruginosa: A. Fraction 1, B. Fraction 2, C. Fraction 3, D. Fraction 4

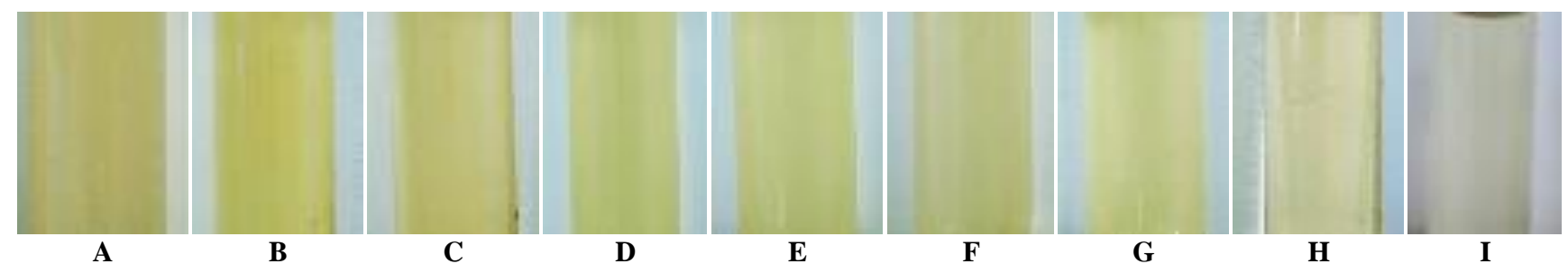

Figure 5. The turbidity fraction 3 of Sansevieria trifasciata leaves in various concentrations: A. Control positive, B. $4 \mathrm{mg} / \mathrm{mL}$, C. 8 $\mathrm{mg} / \mathrm{mL}$, D. $16 \mathrm{mg} / \mathrm{mL}$, E. $32 \mathrm{mg} / \mathrm{mL}$, F. $64 \mathrm{mg} / \mathrm{mL}$, G. $128 \mathrm{mg} / \mathrm{mL}$, H. $256 \mathrm{mg} / \mathrm{mL}$, I. Control negative
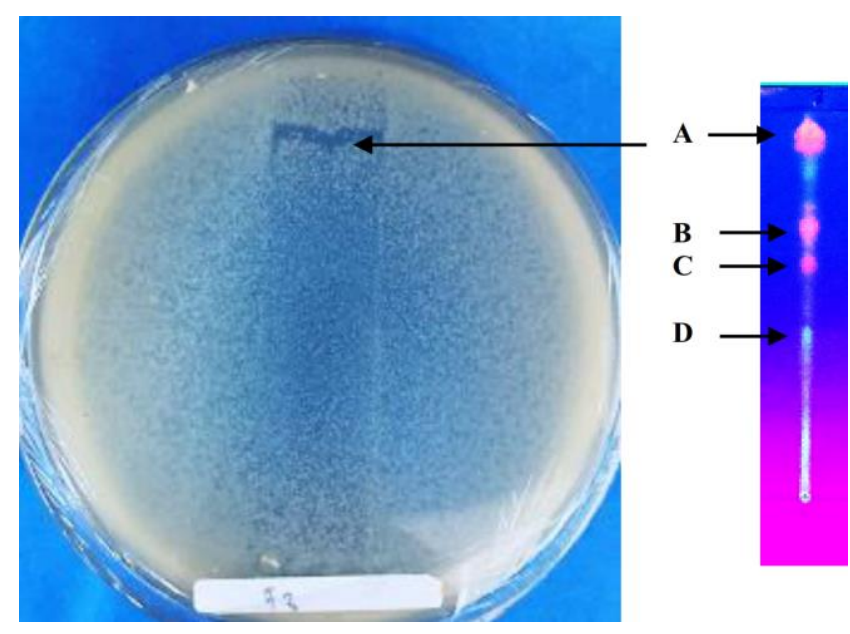

Figure 4. Bioautography fraction 3 of Sansevieria trifasciata leaves: A. Spot 4(Rf 0.93), B. Spot 3(Rf 0.69, C. Spot 2(Rf $0.625)$, D. Spot $1(\operatorname{Rf} 0.44)$

The low antibacterial activity in the present study may be the consequence of different geographical locations in which soil minerals and environmental factors have a great influence on the phytochemical contents of the plant. Secondary metabolites such as phenolics, flavonoids, terpenoids and alkaloids produced from various biochemical processes to crucial environmental stresses, including light irradiation, temperature, soil water, soil

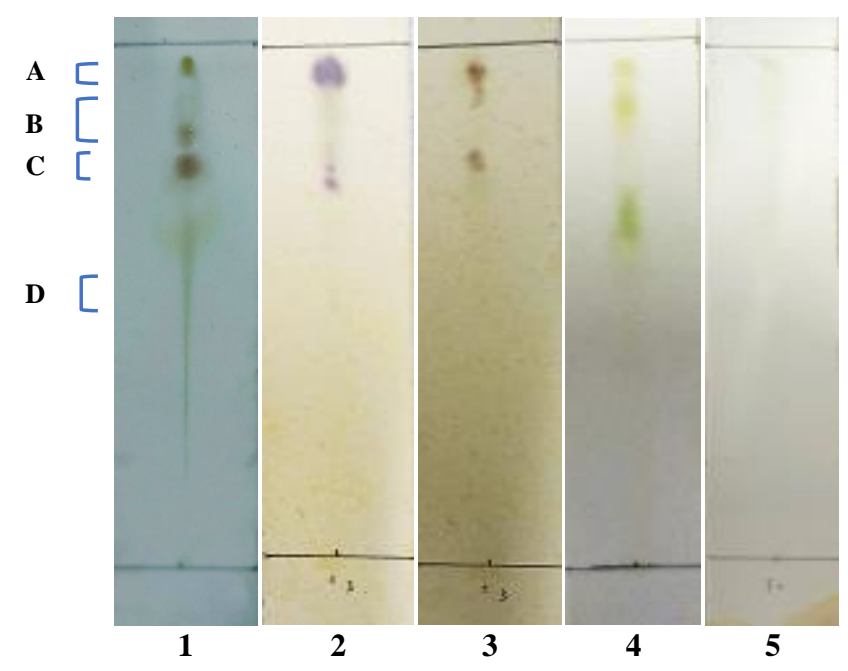

Figure 6. The results of TLC determine the group of bioactive compounds fraction 3 of Sansevieria trifasciata leaves: (1)Terpenoid, (2) Phenolic, (3) Triterpenoid, (4) Flavonoid, (5) Alkaloid. A. Rf 0.93, B. Rf 0.69, C. Rf 0.625, D. Rf 0.44

fertility and salinity. Extracts from the same plant but taken from different areas will produce different active compounds(Prance 1994; Borokini and Ayodele 2012; Yang et al. 2018).

The antibacterial activity of $S$. trifasciata was found very strong with $18 \mathrm{~mm}$ zone of inhibition. Kingsley (2013) reported that the inhibition zone diameter of ethanolic extract of S. trifasciata leaves was $13 \mathrm{~mm}$.. The 
category of inhibition zone i.e. $\geq 20 \mathrm{~mm}$ has very strong antibacterial activity, $10-20 \mathrm{~mm}$ is in a strong category, 5$10 \mathrm{~mm}$ is moderate and $5 \mathrm{~mm}$ is weak (Hudzicki 2016). The results of the inhibition zone showed that the inhibition was higher because in this study extraction was performed with a multilevel maceration method. Multilevel extraction produces certain compounds that are specifically extracted in each solvent used, while single extraction results in less yield and produces not specific compounds. The compound content obtained was higher in multilevel extraction than those of in unstaged extraction (Sulmartiwi et al. 2012).

During the multilevel maceration process, chloroform and ethanol solvents were used. The advantage of this multilevel extraction method is that it can produce large amount of compounds which have different level of polarity. The multilevel extraction was carried out consecutively starting with a non-polar solvent in the form of chloroform and continued with ethanol from a polar solvent (Lisichkov et al. 2014). Ethanol is an efficient organic solvent for use in the extraction of bioactive plant materials. Ethanol is volatile and allows the dissolution of polar compounds such as flavonoid aglycones. This solvent is non-toxic and non-hygroscopic. The antibacterial activity of $S$. trifasciata extract indicates the presence of bioactive compounds. Antibacterial activity is probably due to the presence of alkaloids, saponins, terpenoids, steroids, glycosides, tannins, acid compounds, fats, and oils in their composition (Andhare et al. 2012; Akindele et al. 2015). In this study, after the antibacterial test MIC testing was performed, which is the inhibition value of an antibacterial compound. One of the factors influencing antibacterial activity is the concentration of antibacterial (Frazier and Westhoff 1983). MIC test is a value in which $50 \%$ of the isolates in the test population are inhibited (Schwarz et al 2010). The results showed that $8 \mathrm{mg} / \mathrm{mL}$ MIC concentration inhibited the turbidity of bacteria. This means that at this concentration the $S$. trifasciata leaves extract can reduce or kill the bacterial population up to $\geq 50 \%$. One of the factors influencing antibacterial activity is the concentration of antibacterial substances (Frazier and Westhoff 1983).

The VLC method was used to separate the compounds based on their polarity. Of the four fractions, fraction 3 showed the highest antibacterial activity. Based on the results decrease in antibacterial activity between the crude extract and the fractionation inhibition zone. All crude plant extracts contain several biologically active compounds at very high concentrations. High concentrations of the main compounds can be considered part of the plant's defense system (Hossain et al. 2014). The plant extracts contain many metabolites and compounds, each of which is capable of acting synergistically or antagonistically, these compound components can have the maximum effect if they are in complex conditions along with other compound components (Virganita et al. 2009; Nur and Nugroho 2018). The MIC in this fraction was $32 \mathrm{mg} \mathrm{mL}$. This concentration can reduce the bacterial population by up to $\geq 50 \%$. Fraction 3 allows demonstrating a bacteriostatic effect against $P$. aeruginosa.
The effect of antibacterial components on bacterial cells can cause cell damage. These antibacterial components may be bacteriostatic or bacteriocidal ( $\mathrm{Wu}$ and $\mathrm{Li} 2016$ ). Eve et al. (2020) report that the susceptibility of gramnegative bacteria to antibacterial agents is due to the composition of various cell wall structures such as peptidoglycan, lipids, and cross-linking, which can greatly influence the penetration, binding, and activity of antimicrobial agents. P. aeruginosa is a gram-negative bacterium with a high-fat content in its cell walls (11-22\%). Besides, the cell wall consists of three layers: lipoproteins, phospholipids (outer membrane), and lipopolysaccharides. The presence of a phospholipid outer membrane can reduce the penetration of antibacterial compounds into cells (Fitri and Bustam 2010).

The development of bacterial resistance to currently available antibiotics requires the discovery of new antimicrobial agents. Ciprofloxacin is the most important antibiotics in the treatment of $P$. aeruginosa infections. Ciprofloxacin as positive control is a wide-spectrum antibiotic for the fluoroquinolone class used to treat respiratory infections, urinary tract infections, intraabdominal infections, bone and joint infections, skin and soft tissue infections, and many other infections (Kraatz et al. 2014; Setyorini 2018).

Pseudomonas aeruginosa demonstrates a wide variety of available resistance mechanisms, which can act in combination and even render antibiotics such as ciprofloxacin inoperative (Kraatz et al. 2014; Setyorini 2018; Zhao et al. 2020). Soares et al. (2019) reported that ciprofloxacin first induces bacterial killing of most bacterial cells, but simultaneously activates a strict response mechanism that contributes to the transition of the subpopulation towards the persister phenotype. After the persistent phenotype was expressed, and although the biofilm matrix had unexpected changes, ciprofloxacin failed to eradicate the biofilm.

Phytochemical analysis of fraction showed the presence of various bioactive substances such as triterpenoid, phenolic, terpenoids, and flavonoids. The presence of compounds in the fraction of $S$. trifasciata leaves was associated with antibacterial activity. Terpenoid acts as antiseptic, antimicrobial, antibiotics. It can regulate plant growth, cure skin disorders, and diabetes (Febriyani et al. 2018; Joshee et al. 2019). Flavonoids protect plants from UV radiation, temperature stress and tolerance to heavy metals and insects attack. It also has anticancer, antimicrobial and antiviral activities. Numerous researches have reported that flavonoid compounds can disrupt the integrity of bacterial cell membranes (Harborne 1998; Kristanti and Tunjung 2013).

Ethanolic extracts of the leaves of $S$. trifasciata contain a variety of bioactive compounds that inhibit bacterial growth, further, this extract can be used as a natural antibacterial and antiseptic agent. (Buyun et al. 2018; Tkachenko 2017). Further research is needed to determine the active ingredients of plants that are responsible for the inhibition of $P$. aeruginosa. Also, this study suggests the ethnomedical use of $S$. trifasciata. 


\section{ACKNOWLEDGEMENTS}

We would like to thank the Ministry of Research and Technology/National Research and Innovation Agency of the Republic of Indonesia for supporting the research through PDD grants with contract number 3061/UN1.DITLIT/D IT-LIT/PT/2020. The authors declare that there is no conflict of interest regarding the publication of this paper.

\section{REFERENCES}

Ahamad T, Negi D, Khan MF. 2017. Phytochemical analysis, total phenolic content, antioxidant and antidiabetic activity of Sansevieria cylindrica leaves extract. J Nat Prod Resour 3 (2): 134-136.

Akindele AJ, Wani ZA, Sharma S, Mahajan G, Satti NK, Adeyemi OO, Mondhe DM, Saxena AK. 2015. In vitro and in vivo anticancer activity of root extracts of Sansevieria liberica Gerome \& Labroy (Agavaceae) Evid Based Compl Altern Med 2015: 560404. DOI: $10.1155 / 2015 / 560404$

Andhare RN, Raut MK, Naik SR. 2012. Evaluation of antiallergic and anti-anaphylactic activity of ethanolic extract of Sansevieria trifasciata leaves (EEST) in rodents. J Ethnopharmacol 142 (3): 627 633

Arung ET, Pasedan WF, Kusuma IW, Hendra M, Supriadi MB. 2017. Short communication: Selected medicinal plants in East and North Kalimantan (Indonesia) against Propionibacterium acnes. Biodiversitas 18 (1): 321-325.

Berame J, Cuenca, Sheena M, Marycris L, Manaban. 2017. Phytochemica screening and toxicity level of leaf and root parts extracts of snake plant (Sansevieria trifasciata) using nauplii. Eur J Business Soc Sci 6 (9): 1-11.

Borokini TI and Ayodele AE. 2012. Phytochemical screening of Tacca leontopetaloides (L.) Kuntze collected from four geographical locations in Nigeria. Intl J Modern Bot 2 (4): 97-102. DOI: 10.5923/j.ijmb.20120204.06.

Buyun L, Tkachenko H, Góralczyk A, Maryniuk M, Osadowski Z. 2018. A promising alternative for treatment of bacterial infections by Sansevieria cylindrica Bojer ex Hook leaf extract. Agr Biol Div Imp Nut Health Life Qual 2018: 82-93. DOI: 10.15414/agrobiodiversity.2018.2585-8246.082-93.

Balouiri M, Sadiki M, Saad, Koraichi I. 2016. Methods for in vitro evaluating antimicrobial activity: A review. J Pharmaceutical Analysis: 6 (2): 71-78

Dewanjee S, Gangopadhyay M, Bhattacharya N, Khanra R, Tarun KD. 2014. Bioautography and its scope in the field of natural product chemistry. J Pharm Anal 5 (2): 76-84.

Dzen, S.M, et al. 2003, Bakteriologi Medik. Bayu Media Publishing. Malang, Indonesia. [Indonesian]

Eve A, Aliero AA, Nalubiri D, Adeyemo R O, Akinola SA, Pius T, Nabaasa S, Nabukeera S, Alkali B, Ntulume I. 2020. In vitro antibacterial activity of crude extracts of Artocarpus heterophyllus seeds against selected diarrhoea-causing superbug bacteria. Sci World J 2020: 9813970 DOI: 10.1155/2020/9813970.

Febriyani E, Fallah S, Andrianto D, Lastini D. 2018. Identification of active compounds and anti-acne activity from extracts and fraction of surian (Toona sinensis) leaves planted in Sumedang, West Java, Indonesia. Biodiversitas 19: 1406-1412.

Fitri L, Bustam BM. 2010. Screening of antimicrobial producing strain isolated from the soil of grassland rhizosphere in Pocut Meurah Intan Forest Park, Seulawah, Aceh Besar. Biodiversitas 11 (3): 129-132.

Frazier WC, Westhoff DC. 1983. Food Microbiology. McGraw Hill Co., New York.

Harborne JB. 1998. Phytochemical Methods: A Guide to Modern Techniques of Plant Analysis. 3rd ed. Chapman and Hall, London.

Hossain MA, Al-Hdhrami SS, Weli AM, Al-Riyami Q, Al-Sabahi JN. 2014. Isolation, fractionation and identification of chemical constituents from the leaves crude extracts of Mentha piperita L grown in Sultanate of Oman. Asian Pac J Trop Biomed 4: 368-372.

Jork H, Funk W, Fischer W, Wimmer H. 1994. TLC Reagents \& Detection Methods-Physical \& Chemical Detection Methods:
Activation Reactions, Reagent Sequences, Reagents, II, Vol 1b. Wiley, New York, USA

Joshee N, Dhekney SA, Parajuli P. 2019. Therapeutic and medicinal uses of terpenes. Med Plants 12: 333-359.

Kingsley D, Chauhan R, Sinha P, Abraham J. 2013. Screening and characterization of antimicrobial agents from Sanseveria roxburghiana and Sanseveria trifaciata. Asian J Plant Sci 12 (5): 224227.

Kraatz M, Whitehead TR, Cotta MA, Berhow MA, Rasmussen MA. 2014. Effects of chlorophyll-derived efflux pump inhibitor pheophorbide a and pyropheophorbide a on growth and macrolide antibiotic resistance of indicator and anaerobic swine manure bacteria. Intl $\mathrm{J}$ Antibiotics 14: 1-14.

Khalumba ML, Mbugua PK, Kung'u JB. 2005. Uses and conservation of some highland species of the genus Sansevieria Thunb. in Kenya: African Crop Science Conference Proceedings7: 527-532. Kampala, 5-9 December 2005.

Kristanti H and Sri Tunjung WA. 2013. Detection of alkaloid, flavonoid, terpenoid compounds In bread (Artocarpus communis Forst.) Leaves and pulps: Proceeding The 3rd International Conference on Biological Science: 129-133. Universitas Gadjah Mada, Yogyakarta, 20-21 September 2013. [Indonesian]

Lisichkov K, Kuvendziev S, Zekovic Z, Marinkovski M. 2014. Influence of operating parameters on the supercritical carbon dioxide extraction of bioactive components from common carp (Cyprinus carpio L.) viscera. Sep Purif Technol 138: 191-197.

Matic' S, Stanic S, Mihailovic' M, Bogojevic D. 2016. Cotinus coggygria Scop.: An overview of its chemical constituents, pharmacological and toxicological potential. Saudi J Biol Sci 23: 452-461.

Nur RM and Nugroho LH. 2018. Cytotoxic Activities of Fractions from Dioscorea bulbifera L. Chloroform and Methanol Extracts on T47D Breast Cancer Cells. Pharmacogn j 10 (1): 33-38.

Phillip DC. 2011. Antimicrobial, Antioxidant and Anticancer activity of a hemp plant, Sansevieria roxburghiana Schult. \& Schult. f. [Dissertation]. St. Peter's University, India.

Pinteus S, Rodrigues D, Horta A, Alves C, Thomas OP, Pedrosa R. 2013. Vacuum liquid chromatography (VLC) — an efficient method to enrich phlorotannins extracts from Fucus spiralis. Curr Opin Biotechnol 24S (1): S48-S143.

Prance GT. 1994. Ethnobotany and the Search for New Drugs. Ciba Foundation Symposium vol. 185. John Wiley and Sons, England.

Purwestri YA, Kartikasari N, Putri SG, Wilson W, Sembiring L. 2016. Metabolic profiling of endophytic bacteria from purwoceng (Pimpinella pruatjan Molkend) root and antibacterial activity against Staphylococcus aureus and Pseudomonas aeruginosa. AIP Conf Proc 1744: 020063. DOI: 10.1063/1.4953537.

Retnaningrum E and Wilopo W. 2018. Production and characterization of biosurfactant produced by Pseudomonas aeruginosa B031 isolated from a hydrocarbon phytoremediation field. Biotropia 25: 130-139.

Said AA, Aboutabl EA, El A, Sally A, Raslan MA. 2015. Proximate analysis, phytochemical screening, and bioactivities evaluation of Cissus rotundifolia (Forssk.) Vahl. (Fam. Vitaceae) and Sansevieria cylindrica Bojer ex Hook. (Fam. Dracaenaceae) growing in Egypt. Egyptian Pharmaceut J 14: 180-186.

Schwarz S, Silley P, Simjee S, Woodford N, Van Duijkeren E, Johnson AP, Gaastra W. 2010. Assessing the antimicrobial susceptibility of bacteria obtained from animals. J Antimicrob Chemother 65: 601604.

Setyorini D, Firdaus WAK, Oktiani BW. 2018. Comparison of inhibitory activity of kelakai leaves extract with ciprofloxacin against aggregatibacter Actinomycetemcomitans ATCC ${ }^{\circledR}$ 6514 ${ }^{\mathrm{TM}}$. Dentino 4 (2): 199-204.

Sheela DJ, Jeeva S, Shamila IMR, Packia, Lekshmi NCJ, Raja BJ. 2012. Antimicrobial activity and phytochemical analysis of Sansevieria roxburghiana leaf. Asian J Plant Sci Res 1: 41-44.

Soares A, Roussel V, Pestel-Caron M, Bareau M, Caron F, Bouffartigues E, Chevalier S, Etienne M. 2019. Understanding ciprofloxacin failure in Pseudomonas aeruginosa biofilm: persister cells survive matrix disruption. Front Microbiol 10 (2603): 1-10.

Staples GW, Herbst DRA. 2005. Tropical garden flora: Plants cultivated in the Hawaiian Island and other tropical places. Bishop Museum Press, Honolulu, Hawaii.

Sulmartiwi L, Pujiastuti DY, Tjahjaningsih W and Jariyah. 2018. Potential of mangrove Avicennia rumphiana extract as an antioxidant agent using multilevel extraction. IOP Conf Ser Earth Environ Sci 137: 012075. DOI: 10.1088/1755-1315/137/1/012075. 
Takawira-Nyenya T, Newton LE, Wabuyele E, Stedje B. 2014. Ethnobotanical uses of Sansevieria Thunb. (Asparagaceae) in Coast Province of Kenya. Ethnobot Res Appl 12 (1): 51-69.

Tkachenko H, Buyun L, Osadowski Z, Maryniuk M. 2017. The Antibacterial Activity of Certain Sansevieria Thunb. species against escherichia coli. agrobiodiversity for improving nutrition, health and life quality. Phytochem Lett 22: 39-43.

Umoh UT, Edet VN, Uyoh VE. 2020. Comparative analysis of the phytochemical contents of dry and fresh leaves of Sansevieria trifasciata Prain. Asian J Res Bot 3 (1): 41-47.

Virganita J, Wahyuni DSC, Nugraheni ER. 2009. Antibacterial activity of bioactive compounds from radish (Raphanus sativus) leaves against Escherichia coli and its chemical compounds. Biodiversitas 7 (2): 94 98.

Wu M, Li X. 2016. Molecular Medical Microbiology. 2nd ed. Academic Press, New York, USA.
Wu W, Jin Y, Bai F, Jin S. 2015. Molecular Medical Microbiology. 2nd ed. Academic Press, New York, USA.

Yang L, Wen K, Ruan X, Zhao YX, Wei F, Wang Q. 2018. Response of Plant Secondary Metabolites to Environmental Factors. Molecules 23(762): 1-26.

Yumna L, Angelina, Abdullah, Arbianti R, Utami TS, adn Hermansyah H. 2018. Effect of mother-in-law's tongue leaves (Sansevieria trifasciata) extract's solvent polarity on anti-diabetic activity through in vitro $\alpha$-glucosidase enzyme inhibition test. E3S Web Conf 67: 03003. DOI: $10.1051 / \mathrm{e} 3$ sconf/20186703003.

Zhao L, Wang S, Li X, He X, Jian L. 2020. Development of in vitro resistance to fluoroquinolones in Pseudomonas aeruginosa. Antimicrob Resist Infect Control 9: 124. DOI: 10.1186/s13756-02000793-8. 